Relations industrielles

Industrial Relations

\title{
Temps, travail et modes de vie par Michel LALleMENT, Paris : PUF, collection Sciences sociales et sociétés, 2003, 228 p., ISBN 2-13-053687-5.
}

\section{Jens Thoemmes}

Volume 59, numéro 2, printemps 2004

URI : https://id.erudit.org/iderudit/009554ar

DOI : https://doi.org/10.7202/009554ar

Aller au sommaire du numéro

Éditeur(s)

Département des relations industrielles de l'Université Laval

ISSN

0034-379X (imprimé)

1703-8138 (numérique)

Découvrir la revue

Citer ce compte rendu

Thoemmes, J. (2004). Compte rendu de [Temps, travail et modes de vie par Michel LALLEMENT, Paris : PUF, collection Sciences sociales et sociétés, 2003, 228 p., ISBN 2-13-053687-5.] Relations industrielles / Industrial Relations, 59(2), 436-438. https://doi.org/10.7202/009554ar

Tous droits réservés @ C Département des relations industrielles de l'Universite Laval, 2004
Ce document est protégé par la loi sur le droit d'auteur. L’utilisation des services d'Érudit (y compris la reproduction) est assujettie à sa politique d'utilisation que vous pouvez consulter en ligne.

https://apropos.erudit.org/fr/usagers/politique-dutilisation/ 
previous books, which, confusingly, often make cryptic references to other parts of their parent volume; perhaps it may have been advisable to reedit such chapters in order to eliminate these ambiguities.

Thirdly, despite attempts to address international issues, the collection remains overwhelmingly British in orientation; again, some important debates, such as that surrounding union renewal, receive rather less attention than their importance deserves. Fourthly, the division of sections seems rather arbitrary-for example, the first second half of Volume 5 overlaps with the first of Volume 2. Finally, for what is intended to be a standard reference set-and priced as such - the quality of the binding leaves a great deal to be desired; the cover of the final volume of the review set has already began to peel away. However, none of these limitations detracts from the importance of this collection, and the invaluable insights of the editor. There is little doubt that it will be of great use to academics, practitioners, and students alike.

\section{Temps, travail et modes de vie}

par Michel LALLEMENT, Paris : PUF, collection Sciences sociales et sociétés, 2003, 228 p., ISBN 2-13-053687-5.

L'ouvrage de Michel Lallement, professeur de sociologie au Centre national des arts et métiers à Paris, porte sur des recherches empiriques et collectives interrogeant les temps sociaux. Ce livre tente de faire le point sur les rapports entre temps, travail et modes de vie. Il se présente donc comme un ouvrage de synthèse et de discussion à partir d'un programme de recherche effectué pendant les cinq dernières années. L'originalité de l'ouvrage est sans aucun doute d'inscrire cette série de recherches dans une problématique commune de la rationalisation du temps : du point de vue de l'entreprise et de l'activité professionnelle, mais aussi du point de vue des individus et des contraintes non professionnelles de la vie sociale. Le fil rouge du livre est annoncé sous forme de question dès la première page : «Comment la flexibilité a-t-elle bouleversé les rythmes sociaux des sociétés modernes et, surtout, quelles sont ses implications au quotidien sur le statut et les conditions de vie des salariés ?».

Cette question guide alors les explorations de Michel Lallement dans un exposé en trois parties.
La première partie, intitulée «les rationalisations du temps », propose de contextualiser au plan historique la question posée avec une multitude de faits intéressants et significatifs à relever (chapitre 1), mais aussi par l'élaboration d'une grille d'analyse commune (chapitre 2) permettant d'aborder les questions du temps et du travail avec une perspective qu' on pourrait qualifier de «néo-institutionnaliste » puisant à la fois dans la sociologie durkheimienne et webernienne. Nous reviendrons sur cette approche en fin de note.

La seconde partie, "les mondes vécus de la flexibilité », fait le point sur la construction des catégories d'emploi et du temps, culminant dans l'étude du temps de cadres dont l'auteur montre l'importance pour les « cadres » temporels. Loin d'être un jeu de mots anodin, cette manière de présenter les interrogations touchant à la codification des temps et de l'emploi à partir d'accords d'entreprise « 35 heures», montre qu'on a toujours tort de présupposer l'unité de la catégorie des cadres et celle des temps, alors que le travail de terrain montre la variété des 
solutions envisagées (chapitre 3 et 4). Sont alors abordées deux autres formes temporelles «flexibles»: le travail de nuit à l'hôpital (chapitre 5) et le travail à temps partiel à la poste (chapitre 6). La présentation de ces deux cas permet de comprendre à partir du vécu quotidien les effets de la flexibilité. L'auteur montre que ses effets sont multiples renvoyant d'une part à la promotion d'une rationalisation formelle (mise en cohérence des normes de droits et de l'entreprise) rencontrant des éléments plus matériels (classifications, hiérarchies) : ceci provoque des tensions. L'emploi du cadre apparaît ainsi dans bien des cas comme « contaminant »d'autres statuts d'emploi par des dispositifs similaires du décompte du temps. À propos du travail de nuit, Michel Lallement montre qu'il y a parfois de bonnes raisons d'accepter ce travail pour rationaliser sa vie en conformité avec ses projets de carrière et avec ses projets de famille. Le travail de nuit peut être considéré parfois comme une manière de diviser autrement le travail à l'intérieur du couple permettant une meilleure répartition des tâches domestiques. Ce fait montre que la flexibilité peut se déplacer en aidant à gérer les contraintes non professionnelles. L'emploi à temps partiel semble bien être le signe d'un mécontentement des conditions de travail jugées « insupportables » ou le signe d'une carrière bloquée. En revanche, c'est ce type de flexibilité aussi, qui permet un maintien de l'individu dans son emploi tout en se distinguant de l'emploi à temps plein et de ses conditions de travail peu appréciées.

La troisième partie du livre va situer la question de départ sur la flexibilité dans son contexte international: « ouvertures comparatives ». Il s'agit pour l'auteur non seulement de comprendre la production de statistiques sur le temps, mais aussi d'en montrer les avantages et les faiblesses et, plus généralement, d'attirer l'attention sur la relativité de l'analyse des tendances en fonction des indicateurs retenus d'une part, mais aussi sur la fonction du contexte « sociétal », d'autre part (chapitre 7). D'ailleurs, il ne s'agit pas pour Michel Lallement d'un environnement «sociétal » à analyser, mais bien plus d'une dynamique de société qu'il essaie de retracer autour du travail à temps partiel et autour du travail des cadres. Temps partiel féminin avec un fort taux d'activité et une trajectoire professionnelle continue en France et en Belgique ; temps partiel féminin à faible taux d'activité des femmes (Italie, Espagne, Grèce, Portugal) ; temps partiel comme levier de croissance de l'emploi féminin en général (Allemagne, Autriche, Pays-Bas, Royaume-Uni) et l'existence d'un travail à temps partiel de longue date (Danemark, Finlande, Suède). L'auteur nous montre dans la comparaison France-Suède qu'il y a des dynamiques sociétales endogènes qui créent une norme sociale différente (chapitre 8). Cette construction de norme prend appuie sur des enjeux sociaux différenciés de la flexibilité dans les deux pays, sur un rôle différent du syndicat et de la famille : il s'agit donc pour chaque pays d'une construction sociale singulière.

L'ouvrage de Michel Lallement frappe par la richesse des matériaux mobilisés et par une problématisation nouvelle des questions de flexibilité temporelle. L'appareillage conceptuel et méthodologique cherche à analyser les rapports entre temps et travail au sens de « conditions de travail », au sens d'une généralisation des question du travail à tous les âges de vie (formation, emploi, retraite), mais aussi comme bloc de temps distingué d'autres activités sociales. La grille d'analyse traite du travail comme «institution» durkheimienne à quatre impératifs fonctionnels : l'intégration, la régulation, l'émancipation et la codification. Cette perspective est croisée avec une lecture wébérienne de la rationalisation formelle et matérielle de la vie sociale. Il s'agit ici 
d'une formalisation tout à fait originale et stimulante, car la perspective qui lie l'institution à la rationalisation nous montre aussi les conflits, les ratés et l'effet désorganisateur de la flexibilité sur la production et sur l'organisation des autres activités sociales.

JENS THOEMMES

CNRS

\section{Employment with a Human Face: Balancing Efficiency, Equity, and Voice}

by John BuDD, Ithaca, N.Y.: Cornell University Press, 2004, 263 pp., ISBN

0-8014-4208-7.

A series of oddly shaped dots floats, somewhat haphazardly, across the cover of John Budd's latest book, but this is hardly an accurate picture of the balancing act that he achieves in Employment with a Human Face. Instead, Budd's view of Industrial Relations is a roughly aligned triangle, which despite its symmetry, does not avoid the messy bits that are part and parcel of employment relations research.

It's a tall order to bring together the past century of labour relations research into a cohesive picture, especially if the system in question operates at various levels, from grievances on the shop floor to the globalization of labour standards. But Budd gives it the best shot in recent memory. Employment with a Human Face is really a book out of the blue. As the author admits, it grew not from any specific research agenda but simply from his "effort to create a richer, deeper and more engaging way to teach labour relations and labour policy to his students at the University of Minnesota."

Still, Employment with a Human Face is not a textbook, nor is it for those who insist that employment and work are obvious and well understood concepts. While most industrial relations texts serve as an introduction to existing processes, such as the functioning of collective bargaining or the nature of so-called "work rules", this book kicks it up a notch by successfully weaving together a picture of what the field of pluralist industrial relations is really about — the pursuit of a balance between efficiency, equity and voice in employment.

Budd is an engaging writer with a talent for describing arcane IR topics in a way that is accessible not only to university students, but to anyone with even a passing interest in labour relations. He draws on works as disparate as Pope John Paul II's Centesimus Annus, the United Nations Human Development Report and Uncle Tom's Cabin to advance his ideas, a device that works well most of the time, but which can sometimes be distracting.

There are problems in weaving together a pluralist picture of the world of work, the author notes, beginning with the fact that there are competing claims about "the operation of markets, conflict and power ... and the role of employment in a democratic, capitalist society." These competing streams of thought-from Marxism to Management-share the virtue of being at extreme ends of a spectrum. The Critical or Marxian school views employment as a fundamentally unequal relationship, in which conflict between employer and employee is endemic and where organized labour is a natural and inevitable counterbalance. Human resource management theories assume that the interests of employers and employees can be aligned, thereby mitigating conflict and the need for unions. Pluralist industrial relations scholarship, however, is situated between these extremes and hence is more agnostic about the best way to 